\title{
Colorado Literacy Tutor jako pomoc w nauce i doskonaleniu czytania w języku angielskim dla polskich dzieci
}

\author{
Colorado Literacy Tutor as a support in learning \\ and improving reading in L2 (English) for Polish children
}

\author{
Konrad Juszczyk \\ Instytut Językoznawstwa, Uniwersytet im. Adama Mickiewicza \\ ul. Międzychodzka 5, 60-371 Poznań \\ Centrum Przetwarzania Mowy i Języka, Instytut Filologii Angielskiej \\ Uniwersytet im. Adama Mickiewicza, Collegium Novum \\ al. Niepodległości 4, 61-784 Poznań \\ juszczyk@amu.edu.pl
}

\begin{abstract}
The article below is a short presentation of Colorado Literacy Tutor (CLT ) to Polish readers. CLT is a computer program built to help children in developing literacy skills in English. The main advantage of $C L T$ is the deployment of animated highly interactive interface that enhances both human-computer interaction and the student's learning performance. Designed to help American children, $C L T$ is capable to serve as a learning tool for all children who need to practice reading in English. Since teaching English to Polish children is common in almost all elementary schools and some kindergartens, CLT provides an ideal test bed for research on how Polish children acquire reading abilities in English. The main components of $C L T$ are presented and their impact on reading acquisition is explained. A short preliminary report on author's pilot study is also given.
\end{abstract}

\section{Od elementarza książkowego do elementarza komputerowego}

Tradycja tworzenia materiałów do nauki czytania sięga końca średniowiecza, kiedy to pojawiły się pierwsze europejskie elementarze zwane abecaldnikami. Pierwsze polskie elementarze ukazały się również w postaci abecaldników już w XV i XVI wieku. Były to książeczki prezentujące kolejne litery alfabetu łacińskiego, obok których drukowano teksty religijne - fragmenty pisma świętego i katechizmu (Taboł, 2005). Wraz z rozwojem druku elementarze zawierały coraz więcej kolorowych ilustracji, wierszyków, zagadek, szarad i pouczających opowiastek. Nauka czytania była łączona z zabawą i przygotowaniem do życia (Czarnik, 2004). Jednym ze słynniejszych podręczników dla dzieci był Orbis sensualium pictus Jana Amosa Komeńskiego (Jan Ámos Komenský) wydany w 1658 roku. Podręcznik ten był rozszerzeniem wcześniejszego podręcznika do nauki łaciny - Janua linguarum Reserata (1631:pierwsze wydanie łacińsko-czeskie i łacińsko- 
niemieckie), który został przełożony na szereg języków europejskich ${ }^{1} \mathrm{i}$ azjatyckich ${ }^{2}$. Orbis sensualium pictus obok licznych ustępów objaśniających prawie wszystkie dziedziny życia człowieka zawierał abecadło prezentujące litery alfabetu łacińskiego wraz z ilustracjami zwierząt. Dzieci na podstawie tych ilustracji miały rozpoznać zwierzę i skojarzyć jego głos z brzmieniem i nazwą danej litery. ${ }^{3}$ Abecaldnik Komeńskiego jest zatem początkiem metody głoskowej w nauce czytania ${ }^{4}$. Polska edycja Orbis sensualium pictus ukazała się w 1667 pod tytułem Świat zmysłowy w obrazkach i wraz z innymi przekładami stała się wzorcem dla następnych równie pomysłowo ilustrowanych podręczników dziecięcych.

Przegląd polskich elementarzy od 1550 do 1994 Sebastiana Taboła (Taboł, 2005) ukazuje stopniowe przechodzenie od prezentacji tylko samych liter do ukazywania związków liter z brzmieniem głosek, które symbolizują. Wydane w 1765 roku Nowozebrane obiecadło do sylabizowania y czytania... ${ }^{5}$ ks. Jana Ignacego Feibigera prezentuje litery podobne do siebie pod względem kształtu, a Elementarz dla szkół początkowych z 1875 roku pokazuje litery alfabetu polskiego ułożone według brzmienia i pisowni. W XIX wieku zaczęły ukazywać także elementarze, które przez wprowadzenie wyrazów w formie loteryjek, tabelek oraz jako wyrazów ruchomych miały naukę czytania ułatwić i uprzyjemnić (Taboł, 2005). Współcześnie do nauki czytania przez zabawę zachęcają Klocki $L O G O$ do zabawy i nauki wymowy, czytania, pisania, ortografii i matematyki Bronisława Rocławskiego. Jest to zestaw 150 klocków, które reprezentuja 48 liter polskiego alfabetu rozszerzonego o dwuznaki (ch, cz, ni itd.) i trójznaki (drz, dzi, trz) ${ }^{6}$. Klocki są przeznaczone dla dzieci czteroletnich, które mogą się powoli oswajać z różnicami graficznymi między literami, a później przekonać o symbolicznej funkcji układanych z klocków kompozycji. Starsze dzieci mogą także nauczyć się ortografii. Według twórcy klocków nauka czytania powinna iść $\mathrm{w}$ parze $\mathrm{z}$ nauką pisania (Taboł, 2005) i to właśnie umożliwiają Klocki LOGO. Teoretyczną podstawą nauki jest autorska metoda fonetyczno-literowo-barwna Rocławskiego (Taboł, 2005). W instrukcji dołączonej do zestawu klocków zaproponowano przeróżne zabawy i gry dydaktyczne: układanie wyrazów i krótkich tekstów, okręty z klocków, koło fortuny, ustawianie wież i piramid oraz liczenie klocków (Rocławski). Klocki LOGO rozwijają więc pamięć językową percepcję wzrokową i kształcą manualnie, a także społecznie, bo klockami mogą się bawić całe grupy dzieci w przedszkolu, w domu lub szkole.

Czytelnicy tego artykułu pamiętaja zapewne najsłynniejszy elementarz polski czyli Elementarz Mariana Falskiego, którego metodę nauki czytania określa się jako eklektyczną (Taboł, 2005). Naturalną konsekwencją upowszechnienia nowoczesnych metod druku były coraz barwniejsze i pełniejsze krótkich ilustrowanych opowiastek elementarze i czytanki dla dzieci. W trudnej nauce czytania obok przedszkolanek czy nauczycieli pomagają rodzice i opiekunowie dzieci. Rozwój informatyki i postępująca komputeryzacja życia i edukacji stwarza nowe możliwości. Oto funkcjonują już edukacyjne programy komputerowe, które zarówno umożliwiają uzupełnianie wiedzy oferowanej $\mathrm{w}$ szkole (np. seria eduROM multimedialna baza wiedzy i Gry edukacyjne eduROM wydawane przez Young Digital Poland S.A. ${ }^{7}$ ), jak i pozwalaja na samodzielną naukę czytania (np. eduROM Czytam i piszę wydawany przez Young Digital Poland S.A. ${ }^{8}$ oraz SAM CZYTAM wydany przez Albion ${ }^{9}$ ). Powstało także wiele programów uczących języków obcych, w tym najliczniejsze są kursy języka angielskiego. Dzieci korzystają z nich bardzo chętnie, choć, jak wynika z badań autora, polskie dzieci sześcio- i ośmioletnie mające

\footnotetext{
${ }^{1}$ Angielska edycja Orbis sensualium pictus: http://education.umn.edu/EdPA/iconics/Orbis/Default.htm

${ }^{2}$ Sylwetka J. A. Komeńskiego: http://educ.southern.edu/tour/who/pioneers/comenius.html

${ }^{3}$ Pełna prezentacja liter i obrazków zwierząt w wydaniu niemieckim dostępna w Internecie: http://www.fh-augsburg.de/ harsch/Chronologia/Lspost17/Comenius/com_o00a.html

${ }^{4}$ http://www.literatura.hg.pl/komenski.htm\#_ednref27

${ }^{5}$ Pełny tytuł to: Nowozebrane obiecadło do sylabizowania y czytania dla potrzeby osobliwe Górnego Ślaska szkót po polsku i po niemiecku wyprawione

${ }^{6}$ Ponadto klocki przedstawiają także liczby, znaki matematyczne i interpunkcyjne; niektóre litery powtarzają się, by można było ułożyć więcej wyrazów jednocześnie i całe zdania.

${ }^{7}$ http://www.ydp.com.pl/ydp/multimedia/1027,Multimedialna-baza-wiedzy-eduROM.html

http://www.ydp.com.pl/ydp/multimedia/1075,Gry-edukacyjne-eduROM.html

${ }^{8} \mathrm{http}: / /$ www2.ydp.com.pl/ydp/multimedia/1091,Czytam-i-pisze.html

${ }^{9}$ http://www.albion.pl/katalog/product_info.php?products_id=26
} 
komputer w domu (własny, bądź rodziców) jako jego główne wykorzystanie podają gry komputerowe, a rzadziej programy edukacyjne. Należy tu jednak jeszcze dodać, że dzieci bawiąc się i grając, także uczą się, ale raczej nie są tego świadome, więc nie mówią o tym wprost w wywiadach przeprowadzonych przez autora

Jak wykazują badania nad interakcją komunikacji człowiek-komputer, użytkownicy programów komputerowych wykazują skłonność do traktowania maszyn jak ludzi (Takahashi, 2001). Prawdopodobne jest zatem, iż dzieci w kontakcie $\mathrm{z}$ programem komputerowym będą się zachowywać podobnie jak w kontakcie z ludźmi, a w przypadku programów edukacyjnych, nawiążą z maszyną taki dialog, jak z nauczycielem czy rodzicem. Programem, który uczy czytać i skłania dzieci do społecznych zachowań przed komputerem jest Colorado Literacy Tutor (CLT).

\section{Prezentacja Colorado Literacy Tutor}

Colorado Literacy Tutor to elementarz XXI wieku wykorzystujący najnowsze osiagnięcia w dziedzinie zarówno kształcenia czytania, jak i projektowania systemów komunikacji człowiek-komputer. $C L T^{10}$ został stworzony przez Center for Speech and Language Research ${ }^{11}$ (CSLR) na Uniwersytecie Stanu Kolorado w Boulder (USA). Program został udostępniony dzięki współpracy Centrum Przetwarzania Mowy i Języka (Center for Speech and Language Processing, CSLP) Uniwersytetu im. Adama Mickiewicza w Poznaniu z CSLR. W ramach współpracy Instytut Filologii Angielskiej, a potem założone CSLP wielokrotnie (5 wizyt w latach 2002-2005) gościł dyrektora i założyciela CSLR Ronald'a Cole'a (5 wizyt w latach 2002-2005) oraz inżyniera CSLR Bryana Pelloma (twórcy systemu rozpoznawania mowy SONIC). Dzięki spotkaniom naukowym zaprezentowane zostały badania nad nauką czytania u dzieci i możliwości wspomagania nauki poprzez $C L T$. Delegacja $C S L P$ została także zaproszona do siedziby CSLR w Boulder (USA), gdzie zainspirowana angielską wersją $C L T$ zaczęła tworzyć pierwsze polskie interaktywne książeczki. Zawierały one polski tekst nagrany przez Katarzynę Dziubalską-Kołaczyk i próbny system rozpoznawania mowy oparty na systemie SONIC i korpusie mowy polskiej zebranym przez Mikołaja Wypycha, Grzegorza Krynickiego i Annę Bogacką oraz studentów UAM. Następne próbne książeczki zostały stworzone przez Paulę Orzechowską i Paulinę Zydorowicz oraz Dawida Pietralę i autora niniejszego artykułu. Książeczki były prezentowane na konferencji 36th Poznań Linguistic Meeting $(P L M)^{12}$. Dalsze prace nad spolszczaniem $C L T$ są prowadzone w ramach projektu Polish Literacy Tutor ${ }^{13}$ (PLT) oraz Polish-English Literacy Tutor (PELT). Korpus mowy jest rozwijany - nagrano już 113 dorosłych Polaków oraz 36 dorosłych Polaków mówiących w języku angielskim jako obcym (Polglish), a także 45 dzieci w wieku 10-12 czytających krótkie teksty polskie.

Równolegle w ramach projektu PELT (Bogacka, 2006 i Dziubalska, 2006) platforma CLT jest przystosowywana do nauki wymowy języka angielskiego jako języka obcego dla dorosłych mówiących po polsku jako językiem rodzimym. Zadaniem programu PELT będzie przede wszystkim wykrywanie typowych błędów wymowy popełnianych przez Polaków uczących się języka angielskiego (wstępny przegląd błędów na podstawie korpusu nagrań podaje Dziubalska-Kołaczyk, 2006). System rozpoznawania mowy SONIC jest więc trenowany do rozpoznawania języka angielskiego z polskim akcentem zwanego Polglish (por. Bogacka, 2006)

Kontynuacja prac nad polskim CLT obejmuje także testowanie rozpoznawania mowy polskiej opartego na SONICu i stworzenie serii polskich książeczek interaktywnych oraz ćwiczeń wspomagających czytanie w języku polskim. W dalszej perspektywie planuje się przedstawienie PLT polskim dzieciom w szkole podstawowej. Dlatego konieczne jest sprawdzenie jak dzieci polskie mogą skorzystać z aplikacji uczącej czytać, jak radzą sobie z obsługą komputera oraz jak program skierowany do dzieci amerykańskich stosuje się do dzieci polskich uczących się języka angielskiego.

\footnotetext{
${ }^{10}$ http://www.colit.org/

${ }^{11}$ W skrócie: CSLR. Oficjalna strona internetowa: http://cslr.colorado.edu

${ }^{12} \mathrm{http}: / /$ elex.amu.edu.pl/ifa/plm/2005/

${ }^{13} \mathrm{http}: / /$ elex.amu.edu.pl/ifa/cslp/plt_e.html
} 
Testowany program $C L T$ jest w wersji roboczej, a prace nad jego udoskonaleniem jeszcze trwają. Udostępniona wersja jest wystarczająco funkcjonalna dla wykonania prostych interaktywnych ćwiczeń językowych, które stały się głównym narzędziem badania. Opis CLT oparto na licznych prezentacjach projektu na spotkaniach CSLP i materiałach informacyjnych dostępnych na stronach $C S L R^{14}$ oraz na obserwacjach własnych autora.

Główny cel programu $C L T$ to dostarczenie dziecku narzędzi do nauki przedmiotów szkolnych, ze szczególnym naciskiem na umiejętność sprawnego czytania i rozumienia tekstu. Ćwiczeniu czytania służy seria zadań Foundational Reading Exercises, zwanych także Foundational Reading Skills Tutors czyli ćwiczeń kształcących podstawowe dla czytania sprawności epifonologiczne i metafonologiczne ${ }^{15}$. Następnie kolekcja Interactive Books czyli książek interaktywnych pozwala sprawdzić zdobyte umiejętności w lekturze wspomaganej przez Wirtualna Nauczycielkę. Dla dzieci umiejących już czytać i pisać pakiet CLT oferuje także trening w czytaniu ze zrozumieniem w ramach Summary Street ${ }^{16}$.

Ponadto CLT zapewnia nadzór nad przebiegiem nauki u każdego z uczniów dzięki Managed Learning Environment (czyli monitor postępów w nauce). Wykonywane przez uczniów ćwiczenia i interakcje z komputerem są rejestrowane, a wyniki zbiorcze mogą być prezentowane w postaci wykresów i tabel. Dzięki temu można monitorować postępy uczniów w odniesieniu do założeń programowych dla wybranej grupy dzieci. Postępy dzieci są oceniane za pomocą Assessment Tools (narzędzi ocen). W szczególności ocenia się znajomość alfabetu i świadomość fonologiczną. Narzędzia ocen ułatwiają rozpoznanie problemów w nauce czytania u konkretnych uczniów i dobranie odpowiednich dla nich ćwiczeń korygujących (Wise).

Pakiet CLT składa się więc z pięciu podprogramów: Managed Learning Environment, Assessment Tools, Foundational Reading Skills Tutors, Interactive Books, Summary Street.

\section{Colorado Literacy Tutor: Foundational Reading Skills Tutors}

Program CLT ma przede wszystkim pomóc w nauce czytania przedszkolakom i uczniom pierwszych klas szkoły podstawowej. Wykształceniu niezbędnych dla płynnego czytania umiejętności służą ćwiczenia z serii Foundational Reading Skills Tutors zwane dalej w skrócie Tutors. W obecnej wersji programu udostępniono 35 ćwiczeń rozwijających umiejętności związane z czytaniem w ogóle, a szczególnie związane z czytaniem w języku angielskim. Ćwiczenia te rozwijają szeroko pojętą świadomość fonologiczna, a w szczególności zdolności: (por. Krasowicz-Kupis, 2004):

$>$ różnicowania struktury fonemowej wyrazów i pseudowyrazów17,

$>$ analizy i syntezy sylabowej słów

$>$ rozpoznawania i tworzenia aliteracji,

$>$ wyróżniania nagłosu i wygłosu wyrazów,

$>$ rozpoznawania rymów i rymowania

$>$ dekodowania fonemów z liter,

$>$ rozpoznawania liter

$>$ nazywania liter w języku angielskim

$>$ literowania

Wieloletnie badania międzykulturowe nad nauką czytania wykazały, iż „wprowadzenie ćwiczeń doskonalących analizę fonemową (głoskowa) w przedszkolu przyspiesza sprawne opanowanie czytania" (Łobacz, 1996). Dotyczy to w największym stopniu czytania w językach,

\footnotetext{
${ }^{14} \mathrm{http}: / /$ cslr.colorado.edu/beginweb/reading/reading.html http://cslr.colorado.edu/beginweb/perceptive_animated_interfaces/perceptive_animated_interfaces.html (Cole, 2003) oraz (Wise, [w druku]) http://cslr.colorado.edu/beginweb/virtual_tutor/virtual_tutor.html

${ }^{15}$ Rozróżnienie sprawności epifonologicznych i metafonologicznych zaproponowała Krasowicz-Kupis (2004). Pierwsze obejmują wiedze językową stosowaną raczej automatycznie, bez refleksji ze strony podmiotu i „są niezbędne do pojawienia się późniejszych aktywności metafonologicznych”. Drugie ,ujawniają się poprzez umiejętność identyfikacji elementów fonologicznych i umiejętność manipulowania nimi w sposób intencjonalny” (por. Krasowicz-Kupis, 2004:17, 42). ${ }^{16}$ Nazwa nawiązuje do popularnego programu edukacyjnego Sesame Street z udziałem muppetów Jimiego Hensona.

${ }^{17}$ Pseudowyrazy, a więc wyrazy poprawne fonotaktycznie, lecz nie mające znaczenia, de facto nie pojawiają się w CLT. Jednakże należy założyć, że dla uczących się języka obcego, prawie każdy nowy wyraz jest pseudowyrazem.
} 
w których stosuje się alfabetyczne systemy pisma. Szczegółowe badania podłużne i eksperymentalne udowodniły, że „dwoma najsilniejszymi predyktorami przyszłych osiagnięć w czytaniu są umiejętności fonologiczne dziecka i zdolność do rozpoznawania liter" (Wolf, 2005). U dzieci w wieku 7-9 lat zaobserwowano największy wzrost umiejętności związanych ze świadomością fonologiczną (badania Kaji i wsp. za Krasowicz-Kupis, 2004).

Tutors zostały skonstruowane przez grupę badaczy CSLR kierowaną przez Barbarę Wise, która wcześniej opracowała zestaw ćwiczeń korygujących mowę dziecka Linguistic Remedies. Zarówno Tutors, jak i interaktywne książeczki, zostały oparte na Simple Model of Reading (Prosty model czytania) Gough'a i Tunmer'a. Model ten zakłada, że sprawne czytanie polega na ciągłym współdziałaniu procesów rozpoznawania (dekodowania) wyrazów i rozumienia tekstu. Przyjęto więc, że wielokrotne powtarzanie zadań i odpowiedni instruktaż zapewnią sukcesywne opanowanie zdolności wymienionych powyżej.

Instruktaż jest z kolei realizowany przez stałą obecność Wirtualnej Nauczycielki ${ }^{18} \mathrm{w}$ formie gadającej głowy o twarzy młodej kobiety (są też inne postacie, lecz ta zdaje się być najbardziej przyjazna i najczęściej stosowana). Implementacja animowanej postaci ma na celu nawiązanie i utrzymanie kontaktu uczącego się dziecka z nauczającym go komputerem (programem). To ona wydaje polecenia, objaśnia zasady wykonywania ćwiczenia, zachęca do wysłuchania tekstu i czyta teksty w interaktywnych książkach, a także chwali, gani i poprawia dziecko podczas ćwiczeń. Co ważne, jej głos jest naturalnym nagranym wcześniej głosem ludzkim ${ }^{19}$. Podczas całego ćwiczenia, co parę sekund, nauczycielka (a raczej jej awatar) rusza głową i mruga oczami. To może sprawiać, że uczeń czuje się wciąż obserwowany, tak jakby ktoś nad nim czuwał podczas nauki. Dodatkowo twarz nauczycielki potrafi wyrażać emocje, a więc uśmiecha się, bądź marszczy w reakcji na zachowanie ucznia, co pozwala na nawiązanie kontaktu komputer-dziecko zbliżonego do relacji nauczycielka-uczeń. Co więcej, prawie każde zachowanie (zwłaszcza kliknięcia myszka) wywołuje określone reakcje u Wirtualnej Nauczycielki. Najczęściej czyta ona wskazane litery bądź słowa i ocenia postępy ucznia. Naturalna wymowa jest skorelowana z animacją ust i języka, tak by uczeń mógł rozpoznawać głoski z ruchu warg (visems) i nauczyć się poprawnej wymowy angielskiej. Głowę nauczycielki można obracać, zatem ruchy warg i języka przy wymowie poszczególnych głosek można obserwować nie tylko vis a vis, lecz również z profilu i pozycji pośrednich. Podczas wypowiadania dłuższych komentarzy jej głowa porusza się także pionowo. Animacja awatara jest więc naturalna i prawie w pełni odzwierciedla mimikę prawdziwej nauczycielki.

Prowadzenie ćwiczeń przez wirtualną nauczycielkę jest korzystne dla dzieci, gdyż często mają one problemy z koncentracją lub po prostu nie chcą wykonywać żmudnych ćwiczeń w czytaniu. Twórcy $C L T$ zakładają, że inteligentny (reagujący na działania użytkownika komputera) nauczyciel wirtualny może być równie skuteczny jak żywy. Hipoteza ta została częściowo potwierdzona dzięki badaniom nad nauką czytania już w latach '90 ubiegłego wieku (projekt Reading with ROSS), a także dzięki badaniom nad nauczaniem słownictwa angielskiego u dzieci niedosłyszących i autystycznych (projekt „Baldi”: Cole, 2003). Amerykańskie dzieci, biorące udział w powyższych badaniach, łatwo i chętnie nawiązują kontakt $\mathrm{z}$ awatarem i próbują z nim rozmawiać, mówią o nim np.: Baldi helps me learn (Baldi pomaga mi w nauce) lub Sometimes Baldi doesn't hear what I say. (Czasem Baldi nie styszy, co mówię).

Również polskie dzieci żywo reagują na wypowiedzi Wirtualnej Nauczycielki, co pokazały pilotażowe badania autora, podczas których zarejestrowano częste wypowiedzi dzieci ...dobrze mówi, tak! w reakcji na czytane przez awatara słowa. Fakt, że dzieci rozmawiają z komputerem nie powinien nas dorosłych zresztą dziwić, jak zauważył Ernst Cassirer „,wszystko bowiem, co dziecko otacza >>zagaduje<< je w jakimś sensie. Rzeczy, zjawiska >>zajmują<< je; wchodzą z nim w pewną wspólnotę językową, która dla dziecka oznacza prawdziwą wspólnotę życia." (Cassirer, 2004). Rzeczywiście, dzieci wcale nie są zaskoczone naturalnym głosem, jaki wydobywa się z komputera, ani też animowaną twarzą naśladującą ludzkie emocje - wydaje się, że traktują

\footnotetext{
${ }^{18}$ Prostym i prymitywnym w porównaniu z wirtualną nauczycielką agentem jest np. animowana postać pomocnika w oknie wyszukiwania w systemie Microsoft Windows XP, do wyboru jest 10 różnych postaci: pieski, kotek, czarodziej itp. ${ }^{19}$ Warto podkreślić, iż twórcom CLT zależało na naturalności nagrań i dlatego w programie nie wykorzystano syntezy mowy.
} 
awatara, tak jak nauczycielkę czy przedszkolankę, ożywiają go. Cassirer sugeruje nawet, że dziecko paradoksalnie „rozmawia z rzeczami nie dlatego, iż uważa je za żywe - lecz odwrotnie, uważa je za żywe, ponieważ z nimi rozmawia" (Cassirer, 2004).

Zajęcia z komputerem są oczywiście atrakcyjną zabawą, lecz gdy dziecko ma się czegoś przez zabawę nauczyć, to musi zostać do tego odpowiednio zachęcone i zmotywowane. W tym celu twórcy ćwiczeń zastosowali się do znanego paradygmatu kształcenia przez zabawę wypracowanego na podstawie obserwacji Lwa Wygotskiego i Brunera. Układ elementów przeznaczonych do nauki (np.: słów czy liter) i wskazówki dawane przez program są dostosowane do aktualnych potrzeb danego ucznia wedle zasady rusztowania (scaffolding) wiedzy. Nauka w większości Tutors zaczyna się od elementów, które dziecko poznało już w poprzednim ćwiczeniu dzięki czemu dziecko ma poczucie komfortu psychicznego (comfort level lub zone of proximal development - Daniels, 2001). Następnie przedstawiane są nowe, trudniejsze jednostki, przy czym wyjaśnienia oferowane przez program są tak ograniczone, by dziecko mogło samo odkryć budowę wyrazów czy brzmienie głosek i znaczenie (funkcje) liter (relację do głoski/fonemu). W ten sposób, zgodnie z założeniami Wygotskiego, rozwój poznawczy jest stopniowy, a dziecko zdaje się pracować nad tym samodzielnie i niezależnie. Nauka polega na odkrywaniu pewnych zależności, a następnie na sprawdzaniu ich i upewnianiu się, co do nabytej wiedzy. Strefa poczucia komfortu psychicznego to zakres działań, które dziecko jest w stanie wykonać samodzielnie, w stosunku do tych działań, przy których potrzebuje ono pomocy (por. Kail, 2004). Ćwiczenia są kończone jednostkami już znanymi, tak że dziecko kończy zadanie w strefie komfortu. Metoda rusztowania i strefy komfortu wspiera kreatywność ucznia, przyczynia się do skupienia jego uwagi i samodzielnego poprawiania się. We wszystkich ćwiczeniach Tutors uczący się ma możliwość odsłuchania danego (przez wirtualnego nauczyciela) słowa czy nazwy litery dowolną liczbę razy i dopasowania do niego poprawnej odpowiedzi (najczęściej przez wskazanie jednostki na ekranie i zatwierdzenie kliknięciem myszy).

W CLT zaimplementowano także prosty system gratyfikacji w trakcie wykonywania kolejnych zadań. Zadania mają różne poziomy trudności, a poczynania ucznia są nagradzane za pomocą symbolicznych monet-medali. Podczas całego ćwiczenia, w górnym-prawym rogu ekranu jest mierzony czas, co pozwala na zapanowanie nad czasem jaki dziecko poświęca na dane ćwiczenie. Po wykonaniu pewnego zestawu ćwiczeń określonego typu (dany „tutor”) uczeń może przystapić do testu. Wówczas przebieg ćwiczenia jest ograniczony czasem, a u dołu ekranu widoczny jest skracający się pasek. W przypadku poprawnego wykonania ćwiczenia $\mathrm{w}$ przeznaczonym czasie uczeń otrzymuje nagrodę $\mathrm{w}$ postaci symbolicznych zabawek wyskakujących z pudełka zapakowanego jak prezent.

Wszystkie ćwiczenia są przeznaczone do obsługi myszką, a klikać można dowolnym przyciskiem ${ }^{20}$. Kursor myszki służy do wskazywania liter, obrazków i zatwierdzania odpowiedzi (przycisk OK). Wypowiedzi nauczycielki mogą być powtórzone po naciśnięciu przycisku AGAIN, a pomoc w wykonaniu ćwiczenia uzyskuje się przyciskiem HELP. Wykorzystanie tylko i wyłącznie myszki nie jest wadą programu i nie ogranicza go. Dla dzieci, które miały styczność z komputerem myszka jest najprostszym i najcześsciej używanym (zwłaszcza w Internecie) manipulatorem. Swobodę w posługiwaniu się myszką komputerową dzieci zdobywają zapewne grając $w$ gry komputerowe i korzystając $z$ Internetu.

Możliwość dialogu z komputerem $\mathrm{w}$ takiej formie już przynosi wymierne korzyści. W badaniach CSLR wzięły udział przedszkolaki i dzieci z pierwszych dwóch klas szkół podstawowych w Boulder (stan Kolorado). Sesje nauki trwały po 20 minut dziennie i dzieci po krótkim wprowadzeniu samodzielnie korzystały z CLT z dużym zaangażowaniem i entuzjazmem.

Również badania pilotażowe (autora niniejszego artykułu) polskich dzieci potwierdzaja atrakcyjność i skuteczność interaktywnej nauki czytania, choć w wielu przypadkach polecenia Wirtualnej Nauczycielki musiały być tłumaczone i objaśniane po polsku. Nie oznacza to jednak, że dzieciom potrzebna była pomoc bezpośrednia w wykonaniu zadań, z chwilą poznania reguł

\footnotetext{
${ }^{20} \mathrm{~W}$ myszkach przeznaczonych do pracy na komputerach klasy PC są zawsze co najmniej dwa przyciski o różnych funkcjach, jednakże w programie $C L T$ działanie obu jest takie samo. Dwuklik nie jest używany.
} 
danego zadania na pierwszych przykładach nawet pięciolatki radziły sobie $\mathrm{z}$ kolejnymi przykładami wyśmienicie.

Komunikacja człowiek-komputer w powyższej formie jest przyrównywana przez twórców CSLR do komunikacji „twarza-w-twarz” (face to face communication). Aby jeszcze udoskonalić zindywidualizowaną naukę czytania (one-on-one tutoring) planuje się wdrożenie śledzenia twarzy i wzroku (spojrzenia) i rozpoznawania twarzy ucznia i emocji użytkownika przez program. Wówczas interakcja z komputerem nie będzie się wiele różniła od rozmowy z człowiekiem. Rozpoznawanie mowy już jest dostępne $\mathrm{w}$ interaktywnych książeczkach, pozostałe rozwiązania są testowane.

\section{Colorado Literacy Tutor: Interactive books}

W wirtualnej bibliotece CLT Interactive books dostępne są interaktywne książeczki dla dzieci. Opracowano około sto pozycji w różnych językowo wersjach: angielskiej, hiszpańskiej, włoskiej i francuskiej, a polskie książeczki są w przygotowaniu ${ }^{21}$. Teksty zostały nagrane przez lektorów (native speakerów) i zilustrowane tak, by jak najbardziej przypominały papierowe wydawnictwa. To, co je odróżnia od dawnych elementarzy, to interaktywność osiagnięta przez zastosowanie najnowszych technik analizy mowy i jezzyka.

Nagrania można odsłuchiwać nie tylko dowolną liczbę razy w całości, lecz także wskazać poszczególne słowa by wsłuchać się $\mathrm{w}$ ich wymowę. Wymowę można także na bieżąco obserwować patrząc na ruchy warg Wirtualnej Nauczycielki tak jak w ćwiczeniach Foundational Reading Exercises (FRE).

Umożliwiono także czytanie wspólne z głosem lektora. Wówczas dziecko słucha i obserwuje mimikę awatara i stara się odczytać tekst na głos wraz z nim. Dziecko jest słuchane przez program, bowiem w CLT zastosowano nowoczesny system rozpoznawania mowy $S O N I C^{22}$. Dzięki temu program jest w stanie rozpoznać mowę dziecka i wskazać czytane przez niego wyrazy, a w razie błędnej wymowy - poprawić ja. Przy odczytywaniu tekstu na głos przez dziecko pod tekstem przesuwa się kursor, który sygnalizuje poprawność czytanych wyrazów.

Podczas czytania tekstu, podświetlane są kolejne wyrazy, co ma na celu naukę globalnego rozpoznawania wyrazów. Czytanie globalne jest szczególnie istotne dla języka angielskiego, gdyż uważa się, że jest on klasycznym przykładem ortografii głębokiej (Łobacz, 1996). Ta sama głoska może mieć różne reprezentacje graficzne, a litera może mieć różne interpretacje foniczne zależnie od kontekstu (otoczenia innych głosek i liter) i znaczenia wyrazu. Stąd konieczność zwracania uwagi na związek rozpoznawanych kształtów wyrazów z kontekstem (Kamińska, 1999). Analiza dźwiękowa, rozkład na sylaby i głoski następuje później, po opanowaniu najczęstszych połączeń literowych i ich możliwych czytań. Metoda czytania globalnego jest więc często stosowana w krajach anglosaskich, a także w niektórych ośrodkach nauki języka angielskiego jako obcego w Polsce, w tym w przedszkolu, w którym autor przeprowadził pilotażowe badania. Dla dzieci polskich, które już zaczynają czytać w języku polskim nauka czytania w języka angielskim może naturalnie sprawiać pewne problemy, gdyż język polski ma raczej płytką ortografię. Stosunkowo duża odpowiedniość formy graficznej do dźwiękowej, dużo większa stałość związków litera-głoska, mała liczba wyjątków w regułach czytania, to wszystko może skłaniać dziecko do czytania doliterowego i prób przenoszenia zasad ortografii i ortofonii języka polskiego na język angielski. Z drugiej strony jednak uczący się języków obcych mają przewagę $\mathrm{w}$ zakresie rozwiązywania zadań metajęzykowych, (Wolf, 2005) więc przy odpowiednim treningu i instruktażu szybko nauczą się nowych zasad. Dotyczy to zwłaszcza polskich dzieci, które naukę języka angielskiego rozpoczynają niekiedy już w przedszkolu, a powszechnie także w pierwszych klasach szkoły podstawowej. Konfrontacja polskiej ortografii płytkiej z angielską - głęboką, podczas nauki czytania za pomocą $C L T$ przez polskie dzieci będzie przedmiotem dalszych badań autora.

\footnotetext{
${ }^{21}$ Próbne wersje książeczek były prezentowane na konferencji Poznań Linguistic Meeting 2005, kiedy to udało się pokazać rozpoznawanie mowy $\mathrm{w}$ języku polskim zrealizowane $\mathrm{w}$ ramach projektu Polish Literacy Tutor. http://elex.amu.edu.pl/ifa/plm/2005/index.htm

${ }^{22}$ Więcej na temat SONICa: http://cslr.colorado.edu/beginweb/speech_recognition/sonic.html
} 
Podświetlanie wyrazów przy tekście czytanym przez lektora i przesuwający się kursor pod tekstem czytanym przez dziecko (do mikrofonu) powinno także wykształcić prawidłowe ruchy gałek ocznych. Wodzenie oczami po czytanym tekście nie jest płynne, lecz składa się w większości (93\%-95\% czasu) z fiksacji czyli krótkich (zatrzymań oczu na fragmencie tekstu. Częste są także regresje czyli powroty do początku wiersza w celu upewniania się o czym się czyta. Jak podaje Tinker (1980): „,u dzieci występuje skłonność do chaotycznych ruchów oczu”. Wprawni czytelnicy charakteryzują się generalnie mniejszą liczbą fiksacji i regresji, i jak wynika z badań relacjonowanych przez Tinkera (1980) „największy przyrost i najszybsze tempo wprawy w aktywności okulomotorycznej [czyli ustalania się schematów fiksacji i regresji] podczas czytania zachodzi w pierwszych czterech klasach [szkoły podstawowej]", a dalszą poprawę notuje się w szkole średniej. Program $C L T$ jest przeznaczony dla dzieci od 6 lat (zerówka) do kilkunastu lat (szkoła podstawowa i średnia).

W celu sprawdzenia stopnia zrozumienia tekstu po przeczytaniu fragmentu Wirtualna Nauczycielka zadaje pytania i nakłania dziecko do analizy treści książeczki. Odpowiedzi mogą być dawane przez kliknięcie myszką na fragment tekstu, którego dotyczy pytanie, bądź przez krótkie wypowiedzenie, które zostanie rozpoznane przez komputer ${ }^{23}$. Tak rozpoczyna się nauka czytania ze zrozumieniem, która kontynuowana jest w następnym komponencie CLT-Summary street.

Summary street jest przeznaczony dla dzieci starszych, które czytają już na tyle płynnie by w pełni zrozumieć tekst i umieć go streścić. Streszczenia mogą być pisemne (z klawiatury w odpowiednim oknie komputera) lub ustne (wypowiedziane do mikrofonu i rozpoznane za pomocą systemu rozpoznawania mowy SONIC). Weryfikacja streszczeń ma odbywać się dzięki algorytmom automatycznego przetwarzania języka naturalnego - Latent Semantic Analysis (utajona analiza semantyczna). W niniejszym artykule ograniczono się do wstępnego opisu narzędzi uczących czytać w znaczeniu rozpoznawania liter i wyrazów (lingwistyczne ujęcie czytania wg Brzezińskiej; za Kamińską, 2005), dlatego podprogram Summary Street nie został tu szerzej opisany.

\section{5. Ćwiczenie czytania za pomocą $C L T$ - badania pilotażowe, raport wstępny}

Celem badań prowadzonych przez autora jest przetestowanie skuteczności CLT dla dzieci polskich. Ze względu na specyfikę $C L T$ założono, że dzieci powinny już uczyć się języka angielskiego przynajmniej rok bądź dłużej, by były z nim osłuchane, oswojone i znały podstawowe słownictwo. Jak dotąd przebadano dwie grupy dzieci: sześcioro ośmiolatków uczących się angielskiego dwa lata lub dłużej ${ }^{24}$, ośmioro przedszkolaków w wieku 6 lat $^{25}$ uczących się angielskiego dwa lata. Wszystkie dzieci mają komputer w domu (własny lub rodziców), więc nie stwierdzono problemów z podstawową jego obsługą - wystarczyło pokazać gdzie i w jakim celu należy klikać myszką, a dzieci już orientowały się co robić. W sporadycznych wypadkach, jeśli polecenia Wirtualnej Nauczycielki były niezrozumiałe, autor tłumaczył zasady wykonania konkretnych ćwiczeń. Do badań wybierano ćwiczenia z serii Foundational Reading Exercises (FRE), a ich przebieg zarejestrowano za pomocą programu nagrywającego dźwięk i obraz z ekranu komputera. Wstępna analiza wyników wykazała, że do łatwych ćwiczeń dla badanych dzieci należą te, w których trzeba wskazać literę nazwaną przez Wirtualna Nauczycielkę (np. Lowercase 4-square); albo dopasować słyszaną głoskę do litery (np. Matching Letter - Letter sound). Trudniejsze okazały się naturalnie ćwiczenia wymagające analizy głoskowej wyrazu i ustaleniu jaka litera reprezentuje nagłos słyszanego wyrazu. Dokładna analiza badań pilotażowych może pokazać interakcję zasad ortografii głębokiej języka angielskiego z lepiej znanymi zasadami polskiej płytkiej ortografii i wskazać dalszy kierunek dociekań.

\footnotetext{
${ }^{23}$ Celowo unika się w tym kontekście słowa „zrozumiane”, gdyż program jest ograniczony do przyporządkowania usłyszanej wypowiedzi do przewidzianych możliwych odpowiedzi.

${ }^{24}$ Badania przeprowadzono w Spotecznej Szkole Podstawowej $n r 2$ w Poznaniu dzięki uprzejmości pani dyrektor mgr Agaty Ludwy i za pisemną zgodą rodziców.

${ }^{25}$ Badania przeprowadzono w Anglojęzycznym Przedszkolu Prywatnym w Poznaniu „Akademia Smyka” dzięki uprzejmości pani dyrektor mgr Joanny Radojewskiej i za pisemną zgodą rodziców.
} 
Poniżej zamieszczono dwa fragmenty sesji z programem CLT w ćwiczeniach FRE przerabianych przez 6-letnią Michalinę. Zarejestrowane badania zapisano wg własnej konwencji, która - zgodnie z ogólnie przyjętymi wymogami transkrypcji komunikacji człowiek-komputer (Karpiński, 1998) - ma być:

$>$ nadmiarowa,

$>$ jednoznaczna,

$>$ konsekwentna,

$>$ czytelna.

Oczywiście spełnienie tych wymagań nie zawsze jest możliwe i zależne jest od celu badań. Uznano, że dla opisania interakcji dziecka z komputerem przy nauce i ćwiczeniu czytania w programie $C L T / F R E$ konieczny jest:

$>$ odrębny zapis działań dziecka i działania programu na ekranie (jednoznaczność);

$>$ opis kliknięć i ruchów myszy (patrz przypis 19) i ich skutków widocznych na ekranie,

$>$ odrębny zapis wypowiedzi uczestników dialogu z oznaczeniem „,ról” (jednoznaczność):

○ D: dziecko,

- A: awatar,

○ E: eksperymentator,

$>$ zapis uwzględniający wszystkie wypowiedzi awatara i dziecka oraz wyjaśnień osoby prowadzącej badania ${ }^{26}$ (nadmiarowość);

$>$ komentarz objaśniający przebieg ćwiczenia i interakcji dziecko-komputer (czytelność),

$>$ konsekwentny transkrypt wedle powyższych założeń, bez względu na rodzaj ćwiczenia FRE.

Całość umieszczono w tabeli, która jasno ukazuje działania dziecka (rubryka II:DZIAŁANIA DZIECKA) i jego skutki (w rubryce VI:DZIAŁANIE PROGRAMU NA EKRANIE). Działania zostały ponumerowane (w rubryce I:KROKI), wzorem badań Karpińskiego (1998). Oczywiście działania powtarzają się i każde działanie ma widoczny na ekranie skutek opisany w rubryce VI. Liczba kroków w przebiegu danego zadania może być jednym z mierników umiejętności dziecka, zwłaszcza w porównaniu z osiaggnięciami innych dzieci w kolejnych badaniach.

Tabela pokazuje także dialog dziecka z komputerem i prowadzącym badania (patrz przypis 25) (w rubryce V:DIALOG DZIECKO-AWATAR/EKSPERYMENTATOR) z oznaczeniem ról (rubryka IV:ROLE), a wypowiedzi zostały również ponumerowane (rubryka III:WYP.). Wydaje się, że ze względu na trzech uczestników dialogu, powinno się mówić tu o „trialogu”, albo raczej o „dialogu w triadzie”. Najbezpieczniej będzie jednak użyć znanego terminu - polilogu. Polilog ten jednak nie jest i raczej nie powinien być przyrównywany do rozmowy trojga osób, w którym każdy równie często zwracałby się do pozostałych rozmówców. Ponieważ badania są natury eksperymentalnej, a przedmiotem badania jest interakcja dziecko-komputer, trzeci z rozmówców ma mieć rolę tylko pomocnika w obsłudze programu i komputera. Stąd konwersacja ta wykazuje się dużym stopniem asymetrii, jeśli chodzi udział mówców mierzony liczbą wypowiedzi. W prezentowanym skromnym fragmencie transkryptu jest to stosunek 24:11:9 dla liczby wypowiedzi (odpowiednio) awatara:dziecka:eksperymentatora. Przewiduje się podobny rozkład w pozostałych sesjach.

Ponadto różne są kanały komunikacji:

$>$ dziecko z awatarem komunikuje się:

○ za pomocą myszy, klikając na przyciski, karty ze słowami i literami itp.

○ wypowiedzi dziecka nie są rozpoznawane przez program, choć dziecku może się zdawać, że jest rozumiane, a tym co mówi, ma :wpływ na działanie programu

$>$ awatar $\mathrm{z}$ dzieckiem komunikuje się:

○ za pomocą mowy, a dokładniej systemem nagranych wypowiedzi, których staranny dobór przez program ma sprawić wrażenie konwersacji między uczniem, a nauczycielką

○ za pomocą ekranu, na którym program pokazuje ćwiczenia i rezultaty działań dziecka

\footnotetext{
${ }^{26}$ Prowadzący badania (autor niniejszego artykułu) ograniczał się tylko do asystowania w obsłudze komputera, pomocy w wyjaśnianiu ćwiczeń i niektórych wypowiedzi Wirtualnej Nauczycielki na wyraźną prośbę dziecka.
} 
eksperymentator i dziecko komunikują się za pomocą mowy i tylko w sporadycznych przypadkach, kiedy trzeba pomóc.

$>$ eksperymentator $\mathrm{z}$ awatarem raczej nie prowadzili dialogu, gdyż zamiarem prowadzącego było pozostawienie dziecka $\mathrm{z}$ awatarem ,sam na sam”.

Eksperymentator był obecny przy dziecku (siedział obok) przez cały czas badań. Na obecnym etapie badań nie wiadomo czy można liczyć na to, by dziecko w wieku 6-8 lat mogło samodzielnie korzystać z komputera i wykonywać zadane ćwiczenia. Jednocześnie warto przypomnieć, iż wedle założeń twórców CLT program ma służyć samodzielnej nauce, a awatar ma zastępować nauczycielkę i tak też prowadzone są badania w amerykańskich szkołach (Wise; Cole, 2004). $\mathrm{W}$ planowanych badaniach autora na polskich dzieciach również będzie się do tego dążyć.

Transkrypt I:

\begin{tabular}{|c|c|c|c|c|c|}
\hline $\begin{array}{l}\mathbf{K} \\
\mathbf{R} \\
\mathbf{O} \\
\mathbf{K} \\
\mathbf{I}\end{array}$ & DZIAŁANIA DZIECKA & $\begin{array}{l}\mathbf{W} \\
\mathbf{Y} \\
\mathbf{P}\end{array}$ & $\begin{array}{l}\mathbf{R} \\
\mathbf{O} \\
\mathbf{L} \\
\mathbf{E}\end{array}$ & $\begin{array}{c}\text { DIALOG } \\
\text { DZIECKO-AWATAR/ } \\
\text { EKSPERYMENTATOR }\end{array}$ & $\begin{array}{l}\text { DZIALANIE } \\
\text { PROGRAMU NA } \\
\text { EKRANIE }\end{array}$ \\
\hline I. & II. & III. & IV. & V. & VI. \\
\hline \multirow[t]{3}{*}{1.} & $\begin{array}{lll}\text { kliknięcie } & \text { na } & \text { obrazek } \\
\text { Matching } & & \\
\end{array}$ & 1. & A: & Matching & $\begin{array}{ll}\text { wybór } & \text { ćwiczenia } \\
\text { Matching } & \\
\end{array}$ \\
\hline & & 2. & A: & $\begin{array}{l}\text { Welcome to the Matching } \\
\text { Game! }\end{array}$ & \\
\hline & & 3. & A: & $\begin{array}{l}\text { Find the two pictures that } \\
\text { match. }\end{array}$ & $\begin{array}{lr}\text { sześć żółtych } & \text { kart } \\
\text { "zakrywa" } \\
\text { wyrazów }\end{array}$ \\
\hline \multirow[t]{2}{*}{2.} & $\begin{array}{l}\text { wodzenie kursorem } \\
\text { myszki po ekranie }\end{array}$ & 4. & D: & $\begin{array}{l}\text { którym klawiszem, lewym } \\
\text { czy prawym? }\end{array}$ & \\
\hline & & 5. & E: & którymkolwiek & \\
\hline 3. & $\begin{array}{l}\text { kliknięcie na jedną } \mathrm{z} \\
\text { żółtych kart }\end{array}$ & 6. & A: & bed & $\begin{array}{l}\text { karta podświetla się, } \\
\text { a awatar wypowiada } \\
\text { słowo }\end{array}$ \\
\hline \multirow[t]{3}{*}{4.} & $\begin{array}{l}\text { kliknięcie na jedną } \mathrm{z} \\
\text { żółtych kart }\end{array}$ & 7. & A: & bed & $\begin{array}{l}\text { karta podświetla sie, } \\
\text { a awatar wypowiada } \\
\text { słowo }\end{array}$ \\
\hline & & 8. & D: & ja nie wiem co to znaczy & \\
\hline & & 9. & E: & $\begin{array}{l}\text { posłuchaj co ona mówi i } \\
\text { zobacz inny przykład }\end{array}$ & \\
\hline \multirow[t]{8}{*}{5.} & $\begin{array}{l}\text { kliknięcie na jedną } \mathrm{z} \\
\text { żółtych kart }\end{array}$ & 10. & A: & bag & $\begin{array}{l}\text { karta podświetla się, } \\
\text { a awatar wypowiada } \\
\text { słowo }\end{array}$ \\
\hline & & 11. & E: & pasuje do siebie? & \\
\hline & & 12. & D: & no nie wiem & \\
\hline & & 13. & E: & a brzmi? tak samo? & \\
\hline & & 14. & D: & podobnie & \\
\hline & & 15. & E: & tak samo czy podobnie? & \\
\hline & & 16. & D: & hmm & \\
\hline & & 17. & E: & no to jeszcze raz & \\
\hline
\end{tabular}


Konrad Juszczyk: Colorado Literacy Tutor jako pomoc w nauce i doskonaleniu czytaniaw języku angielskim dla polskich dzieci

\begin{tabular}{|c|c|c|c|c|c|}
\hline 6. & $\begin{array}{l}\text { kliknięcie na jedną } \mathrm{z} \\
\text { żółtych kart }\end{array}$ & 18. & A: & bed & $\begin{array}{l}\text { karta podświetla się, } \\
\text { a awatar wypowiada } \\
\text { słowo }\end{array}$ \\
\hline \multirow[t]{5}{*}{7.} & $\begin{array}{l}\text { kliknięcie na jedną } \mathrm{z} \\
\text { żółtych kart }\end{array}$ & 19. & A: & bag & $\begin{array}{l}\text { karta podświetla się, } \\
\text { a awatar wypowiada } \\
\text { słowo }\end{array}$ \\
\hline & & 20. & D: & inaczej chyba & \\
\hline & & 21. & E: & to wtedy not match & \\
\hline & & 22. & D: & tu? & \\
\hline & & 23. & E: & aha & \\
\hline 8. & $\begin{array}{l}\text { kliknięcie na przycisk } \\
\text { NOT MATCH }\end{array}$ & & & & $\begin{array}{l}\text { wyrazy są z powrotem } \\
\text { zakrywane przez karty }\end{array}$ \\
\hline 9. & $\begin{array}{l}\text { kliknięcie na jedną } \mathrm{z} \\
\text { żółtych kart }\end{array}$ & 24. & A: & bed & $\begin{array}{l}\text { karta podświetla się, } \\
\text { a awatar wypowiada } \\
\text { słowo }\end{array}$ \\
\hline \multirow[t]{3}{*}{10.} & $\begin{array}{l}\text { kliknięcie na jedną } \mathrm{z} \\
\text { żółtych kart }\end{array}$ & 25. & A: & bed & $\begin{array}{l}\text { karta podświetla się, } \\
\text { a awatar wypowiada } \\
\text { słowo }\end{array}$ \\
\hline & & 26. & D: & tak samo & \\
\hline & & 27. & E: & match, ok? & \\
\hline 11. & $\begin{array}{l}\text { kliknięcie na przycisk } \\
\text { MATCH }\end{array}$ & & & & $\begin{array}{l}\text { pozostają cztery karty pod } \\
\text { kartami pojawia się } \\
\text { wymawiane słowo bed }\end{array}$ \\
\hline 12. & $\begin{array}{l}\text { kliknięcie na jedną } \mathrm{z} \\
\text { żółtych kart }\end{array}$ & 28. & A: & bag & $\begin{array}{l}\text { karta podświetla się, } \\
\text { a awatar wypowiada } \\
\text { słowo }\end{array}$ \\
\hline 13. & $\begin{array}{l}\text { kliknięcie na jedną } \mathrm{z} \\
\text { żółtych kart }\end{array}$ & 29. & A: & pin & $\begin{array}{l}\text { karta podświetla się, } \\
\text { a awatar wypowiada } \\
\text { słowo }\end{array}$ \\
\hline 14. & $\begin{array}{l}\text { kliknięcie na przycisk } \\
\text { NOT MATCH }\end{array}$ & & & & \\
\hline 15. & $\begin{array}{l}\text { kliknięcie na jedną } \mathrm{z} \\
\text { żółtych kart }\end{array}$ & 30. & A: & pin & $\begin{array}{l}\text { karta podświetla się, } \\
\text { a awatar wypowiada } \\
\text { słowo }\end{array}$ \\
\hline 16. & $\begin{array}{l}\text { kliknięcie na jedną } \mathrm{z} \\
\text { żółtych kart }\end{array}$ & 31. & A: & bag & $\begin{array}{l}\text { karta podświetla się, } \\
\text { a awatar wypowiada } \\
\text { słowo }\end{array}$ \\
\hline 17. & $\begin{array}{l}\text { kliknięcie na przycisk } \\
\text { NOT MATCH }\end{array}$ & & & & \\
\hline 18. & $\begin{array}{l}\text { kliknięcie na jedną } \mathrm{z} \\
\text { żółtych kart }\end{array}$ & 32. & A: & bag & $\begin{array}{l}\text { karta podświetla się, } \\
\text { a awatar wypowiada } \\
\text { słowo }\end{array}$ \\
\hline 19. & $\begin{array}{l}\text { kliknięcie na jedną } \mathrm{z} \\
\text { żółtych kart }\end{array}$ & 33. & A: & pin & $\begin{array}{l}\text { karta podświetla się, } \\
\text { a awatar wypowiada } \\
\text { słowo }\end{array}$ \\
\hline 20. & $\begin{array}{l}\text { kliknięcie na przycisk } \\
\text { NOT MATCH }\end{array}$ & & & & \\
\hline 21. & $\begin{array}{l}\text { kliknięcie na jedną } \mathrm{z} \\
\text { żółtych kart }\end{array}$ & 34. & A: & bag & $\begin{array}{l}\text { karta podświetla się, } \\
\text { a awatar wypowiada } \\
\text { słowo }\end{array}$ \\
\hline 22. & $\begin{array}{l}\text { kliknięcie na jedną } \mathrm{z} \\
\text { żółtych kart }\end{array}$ & 35. & A: & pin & $\begin{array}{l}\text { karta podświetla się, } \\
\text { a awatar wypowiada } \\
\text { słowo }\end{array}$ \\
\hline
\end{tabular}




\begin{tabular}{|c|c|c|c|c|c|}
\hline 23. & $\begin{array}{l}\text { kliknięcie na przycisk } \\
\text { NOT MATCH }\end{array}$ & & & & \\
\hline 24. & $\begin{array}{l}\text { kliknięcie na jedną } \mathrm{z} \\
\text { żółtych kart }\end{array}$ & 36. & A: & bag & $\begin{array}{l}\text { karta podświetla się, } \\
\text { a awatar wypowiada } \\
\text { słowo }\end{array}$ \\
\hline 25. & $\begin{array}{l}\text { kliknięcie na jedną } \mathrm{z} \\
\text { żółtych kart }\end{array}$ & 37. & A: & bag & $\begin{array}{l}\text { karta podświetla się, } \\
\text { a awatar wypowiada } \\
\text { słowo }\end{array}$ \\
\hline \multirow[t]{5}{*}{26.} & $\begin{array}{l}\text { kliknięcie na przycisk } \\
\text { МАTCH }\end{array}$ & & & & $\begin{array}{l}\text { pozostają dwie karty } \\
\text { słowo bag pojawia sie } \\
\text { u dołu ekranu }\end{array}$ \\
\hline & & 38. & D: & dobrze & \\
\hline & & 39. & A: & you got it & \\
\hline & & 40. & D: & dobrze & \\
\hline & & 41. & D: & no, ostatnie & \\
\hline 27. & $\begin{array}{l}\text { kliknięcie na jedną } \mathrm{z} \\
\text { żółtych kart }\end{array}$ & 42. & A: & pin & $\begin{array}{l}\text { karta podświetla się, } \\
\text { a awatar wypowiada } \\
\text { słowo }\end{array}$ \\
\hline 28. & $\begin{array}{l}\text { kliknięcie na jedną } \mathrm{z} \\
\text { żółtych kart }\end{array}$ & 43. & A: & pin & $\begin{array}{l}\text { karta podświetla się, } \\
\text { a awatar wypowiada } \\
\text { słowo }\end{array}$ \\
\hline \multirow[t]{2}{*}{29.} & $\begin{array}{l}\text { kliknięcie na przycisk } \\
\text { MATCH }\end{array}$ & & & & $\begin{array}{l}\text { słowo pin pojawia sie } \\
\text { u dołu ekranu }\end{array}$ \\
\hline & & 44. & A: & click on arrow to continue & \\
\hline
\end{tabular}

Wykonanie ćwiczenia zajęło trzy i pół minuty i odbyło się bez poważniejszych problemów. Kolejne wiersze tabeli ukazują sekwencję zdarzeń w interakcji dziecko-komputer. Prześledźmy ją skrótowo, krok po kroku:

1: $\quad$ wybrano ćwiczenie Matching, Wirtualna Nauczycielka wita ucznia i wyjaśnia ćwiczenie, które polega na dopasowaniu słyszanego wyrazu z wyrazem napisanym na ekranie

2: $\quad$ wodzenie kursorem po ekranie uwzględniono jako działanie dziecka, mimo że, program raczej na to nie reaguje. Jednakowoż należy pamiętać, iż awatar Wirtualnej Nauczycielki stara się utrzymać kontakt z uczniem mrugając oczami i ruszając głową podczas ćwiczenia, także w czasie ,nieklikania”. Co więcej, jak zauważył w swoich badaniach Karpiński (1998), wodzenie może pomóc użytkownikowi w koncentracji na danej części ekranu.

2-11: Michalina nie była pewna, jak wykonać ćwiczenie, stąd dodatkowe wyjaśnienia prowadzącego badania (wypowiedzi oznaczone E:) były konieczne tylko na początku ćwiczenia.

6-8: $\quad$ para wyrazów bed:bag jest heterofoniczna i stanowi parę minimalną [bæd]:[bæg] czym Michalina nie jest przekonana, ale skoro mówi: ,inaczej chyba”, to zasugerowano kliknięcie na przycisk NOT MATCH.

9-10: $\quad$ w momencie odkrycia kart z wyrazem bed w postaci nagrania i napisu Michalina zaczyna rozumieć sens ćwiczenia, zauważa, że napis zgadza się z wypowiadanym słowem i dlatego zasugerowano naciśnięcie przycisku MATCH.

11-29: dalej Michalina wykonuje ćwiczenie już samodzielnie, klika na karty i ustala pary.

38/40-41: Michalina sama komentuje przebieg ćwiczenia, chwaląc się, że dobrze je robi.

Jak widać, Michalina szybko nauczyła się jak wykonać powyższe ćwiczenie, pozornie proste i banalne, lecz wymagające przecież elementarnych umiejętności metajęzykowych - identyfikacji i dyskryminacji wypowiedzi w obcym języku oraz komputerowych - poruszania i klikania myszką. 
Drugi transkrypt ukazuje przebieg ćwiczenia Letters-Sounds 4 square. Transkrypcja i tabela są spójne z poprzednim transkryptem. Ćwiczenie jest dłuższe i trudniejsze, gdyż zadaniem dziecka jest wybrać literę, która zaczyna wypowiadane słowo (A:Click on the first letter in pop), bądź oznacza daną głoskę (A:Choose the letter that says $f$ ). Na ekranie są zawsze 4 litery do wyboru. Michalina po krótkim rozeznaniu zaczęła robić ćwiczenie poprawnie, choć, jak się zdaje, nie rozumiała poleceń Wirtualnej Nauczycielki dokładnie.

Transkrypt II:

\begin{tabular}{|c|c|c|c|c|c|}
\hline $\begin{array}{l}\mathbf{K} \\
\mathbf{R} \\
\mathbf{O} \\
\mathbf{K} \\
\mathbf{I} \\
\end{array}$ & DZIALANIA DZIECKA & $\begin{array}{l}\mathbf{W} \\
\mathbf{Y} \\
\mathbf{P}\end{array}$ & $\begin{array}{l}\mathbf{R} \\
\mathbf{O} \\
\mathbf{L} \\
\mathbf{E}\end{array}$ & $\begin{array}{c}\text { DIALOG } \\
\text { DZIECKO-AWATAR/ } \\
\text { EKSPERYMENTATOR }\end{array}$ & $\begin{array}{c}\text { DZIALANIE } \\
\text { PROGRAMU NA } \\
\text { EKRANIE }\end{array}$ \\
\hline \multirow[t]{3}{*}{ I. } & II. & III. & IV. & V. & VI. \\
\hline & & 1. & A: & $\begin{array}{l}\text { Time to strengthen letter } \\
\text { sound tools }\end{array}$ & $\begin{array}{l}\text { cztery duże przyciski } \\
\text { oznaczone literami: } \\
\mathbf{p}, \mathbf{t}, \mathbf{c}, \mathbf{g}\end{array}$ \\
\hline & & 2. & A: & $\begin{array}{l}\text { Click on the first letter in } \\
\text { pop }\end{array}$ & \\
\hline 1. & kliknięcie na AGAIN & 3. & A: & $\begin{array}{l}\text { Click on the first letter in } \\
\text { pop }\end{array}$ & \\
\hline \multirow[t]{5}{*}{2.} & kliknięcie na $\mathrm{p}$ & 4. & A: & pi & \\
\hline & & 5. & D: & nie, nie wiem & \\
\hline & & 6. & E: & czemu nie? & \\
\hline & & 7. & D: & bo nawet nie wiem & \\
\hline & & 8. & E: & $\begin{array}{l}\text { no to kliknij OK. i } \\
\text { przekonamy się }\end{array}$ & \\
\hline \multirow[t]{4}{*}{3.} & kliknięcie na OK & & & & $\begin{array}{l}\text { złota moneta za odpowiedź } \\
\text { bez pomyłki }\end{array}$ \\
\hline & & 9. & A: & $\begin{array}{l}\text { Choose the first letter in } \\
\text { big }\end{array}$ & $\begin{array}{l}\text { nowe litery do wyboru: } \\
\mathbf{t}, \mathbf{p}, \mathbf{b}, \mathbf{k}\end{array}$ \\
\hline & & 10. & D: & big? & \\
\hline & & 11. & E: & uhm & \\
\hline \multirow[t]{2}{*}{4.} & kliknięcie na b & 12. & A: & bi & \\
\hline & & 13. & D: & bi & \\
\hline \multirow[t]{2}{*}{5.} & kliknięcie na b & 14. & A: & bi & \\
\hline & & 15. & D: & bi & \\
\hline \multirow[t]{3}{*}{6.} & kliknięcie na OK & & & & $\begin{array}{l}\text { druga złota moneta za } \\
\text { odpowiedź bez pomyłki }\end{array}$ \\
\hline & & 16. & A: & $\begin{array}{l}\text { Choose the letter that says } \\
\mathrm{f}\end{array}$ & $\begin{array}{l}\text { nowe litery do wyboru: } \\
\text { d, } \mathbf{g}, \mathbf{f}, \mathbf{b}\end{array}$ \\
\hline & & 17. & A: & $\mathrm{f}$ & \\
\hline \multirow[t]{3}{*}{7.} & kliknięcie na f & 18. & A: & right again! & \\
\hline & & 19. & A: & ef & \\
\hline & & 20. & A: & $\begin{array}{l}\text { You're doing great, do you } \\
\text { want to do the test now? }\end{array}$ & $\begin{array}{l}\text { trzecia złota moneta za } \\
\text { odpowiedź bez pomyłki }\end{array}$ \\
\hline
\end{tabular}




\begin{tabular}{|c|c|c|c|c|c|}
\hline & & 21. & A: & $\begin{array}{l}\text { Click on test, if you want } \\
\text { to do the test; }\end{array}$ & \\
\hline & & 22. & A: & $\begin{array}{l}\text { if not, we will practice } \\
\text { more }\end{array}$ & \\
\hline & & 23. & A: & OK, let's practice more & \\
\hline & & 24. & A: & $\begin{array}{l}\text { Choose the letter that says } \\
\text { p }\end{array}$ & \\
\hline 8. & kliknięcie na $\mathrm{p}$ & 25. & A: & pi & \\
\hline \multirow[t]{2}{*}{9.} & kliknięcie na OK & 26. & A: & pi & \\
\hline & & 27. & A: & $\begin{array}{l}\text { Choose the letter that says } \\
\text { b }\end{array}$ & $\begin{array}{l}\text { nowe litery do wyboru: } \\
\mathbf{b}, \mathbf{t}, \mathbf{d}, \mathbf{f}\end{array}$ \\
\hline 10. & kliknięcie na b & 28. & A: & $\mathrm{b}$ & \\
\hline \multirow[t]{3}{*}{11.} & kliknięcie na OK. & 29. & A: & bi & $\begin{array}{l}\text { piąta złota moneta za } \\
\text { odpowiedź bez pomyłki }\end{array}$ \\
\hline & & 30. & A: & You're doing great! & $\begin{array}{l}\text { nowe litery do wyboru: } \\
\text { th, f, }, \mathbf{g}, \mathbf{d}\end{array}$ \\
\hline & & 31. & A: & $\begin{array}{l}\text { Choose the letter that says } \\
\text { f }\end{array}$ & \\
\hline 12. & kliknięcie na $\mathrm{f}$ & 32. & A: & $\mathrm{f}$ & \\
\hline \multirow[t]{3}{*}{13.} & kliknięcie na OK. & 33. & A: & Torrific! & \\
\hline & & 34. & A: & ef & $\begin{array}{l}\text { szósta złota moneta za } \\
\text { odpowiedź bez pomyłki }\end{array}$ \\
\hline & & 35. & A: & $\begin{array}{l}\text { Choose the letter that says } \\
\mathrm{p}\end{array}$ & $\begin{array}{l}\text { nowe litery do wyboru: } \\
\mathbf{c}, \mathbf{p}, \mathbf{f}, \mathbf{v}\end{array}$ \\
\hline 14. & kliknięcie na $\mathrm{p}$ & 36. & A: & $\mathrm{p}$ & \\
\hline \multirow[t]{4}{*}{15.} & kliknięcie na OK. & 37. & A: & You're awesome! & \\
\hline & & 38. & A: & pi & $\begin{array}{l}\text { siódma złota moneta za } \\
\text { odpowiedź bez pomyłki }\end{array}$ \\
\hline & & 39. & A: & You're doing great! & $\begin{array}{l}\text { nowe litery do wyboru: } \\
\mathbf{f , p}, \mathbf{p}, \mathbf{t}\end{array}$ \\
\hline & & 40. & A: & Find the letter that says $f$ & \\
\hline 16. & kliknięcie na f & 41. & A: & $\mathrm{f}$ & \\
\hline \multirow[t]{4}{*}{17.} & kliknięcie na OK & 42. & A: & Too cool! & \\
\hline & & 43. & A: & ef & $\begin{array}{l}\text { ósma złota moneta za } \\
\text { odpowiedź bez pomyłki }\end{array}$ \\
\hline & & 44. & A: & $\begin{array}{l}\text { You're doing well and } \\
\text { you're ready for a test! }\end{array}$ & \\
\hline & & 45. & A: & OK, let's do the test. & \\
\hline 18. & kliknięcie na TEST & & & & $\begin{array}{l}\text { U dołu ekranu znajduje się } \\
\text { ikona - dłoń trzymająca } \\
\text { stoper, a obok ,skala } \\
\text { czasu” w postaci kolejno } \\
\text { znikających kresek z lewej } \\
\text { do prawej strony ekranu }\end{array}$ \\
\hline
\end{tabular}


Konrad Juszczyk: Colorado Literacy Tutor jako pomoc w nauce i doskonaleniu czytaniaw języku angielskim dla polskich dzieci

\begin{tabular}{|c|c|c|c|c|c|}
\hline & & 46. & & Find the first letter in base & $\begin{array}{l}\text { nowe litery do wyboru: } \\
\text { b, g, d, v kliknięcie na } \\
\text { literę podczas testu } \\
\text { wywołuje tylko dźwięk } \\
\text { potwierdzenia, bądź } \\
\text { dźwięk błędnej odpowiedzi }\end{array}$ \\
\hline \multirow[t]{2}{*}{19.} & kliknięcie na b & & & & $\begin{array}{l}\text { pierwsza złota moneta } \\
\text { za poprawną odpowiedź } \\
\text { przycisk z literą zapala się } \\
\text { na zielono }\end{array}$ \\
\hline & & 47. & A: & Find the first letter in pod & $\begin{array}{l}\text { nowe litery do wyboru: } \\
\mathbf{p}, \mathbf{b}, \mathbf{g}, \mathbf{t h}\end{array}$ \\
\hline \multirow[t]{2}{*}{20.} & kliknięcie na p & & & & $\begin{array}{l}\text { druga złota moneta } \\
\text { za poprawną odpowiedź } \\
\text { przycisk z literą zapala się } \\
\text { na zielono }\end{array}$ \\
\hline & & 48. & A: & $\begin{array}{l}\text { Click on the letter that says } \\
\mathrm{b}\end{array}$ & $\begin{array}{l}\text { nowe litery do wyboru: } \\
\mathbf{g}, \mathbf{f}, \mathbf{b}, \mathbf{t}\end{array}$ \\
\hline \multirow[t]{2}{*}{21.} & kliknięcie na b & & & & $\begin{array}{l}\text { trzecia złota moneta za } \\
\text { poprawną odpowiedź } \\
\text { przycisk z literą zapala się } \\
\text { na zielono }\end{array}$ \\
\hline & & 49. & A: & $\begin{array}{l}\text { Click on the letter that says } \\
\mathrm{f}\end{array}$ & $\begin{array}{l}\text { nowe litery do wyboru: } \\
\mathbf{d}, \mathbf{b}, \mathbf{f}, \text { th }\end{array}$ \\
\hline \multirow[t]{2}{*}{22.} & kliknięcie na f & & & & $\begin{array}{l}\text { czwarta złota moneta za } \\
\text { poprawną odpowiedź } \\
\text { przycisk z literą zapala się } \\
\text { na zielono }\end{array}$ \\
\hline & & 50. & A: & $\begin{array}{l}\text { Click on the letter that says } \\
\text { b }\end{array}$ & $\begin{array}{l}\text { nowe litery do wyboru: } \\
\mathbf{d}, \mathbf{b}, \mathbf{p}, \mathbf{k}\end{array}$ \\
\hline \multirow[t]{2}{*}{23.} & kliknięcie na $\mathrm{p}$ & & & & $\begin{array}{l}\text { brązowa moneta za błędną } \\
\text { odpowiedź, przycisk z } \\
\text { literą zapala się na } \\
\text { czerwono }\end{array}$ \\
\hline & & 51. & A: & $\begin{array}{l}\text { Choose the letter that says } \\
\mathrm{p}\end{array}$ & $\begin{array}{l}\text { nowe litery do wyboru: } \\
\mathbf{g}, \mathbf{p}, \mathbf{t h}, \mathbf{b}\end{array}$ \\
\hline \multirow[t]{2}{*}{24.} & kliknięcie na p & & & & $\begin{array}{l}\text { piąta złota moneta za } \\
\text { poprawną odpowiedź } \\
\text { przycisk z literą zapala się } \\
\text { na zielono }\end{array}$ \\
\hline & & 52. & A: & Find the first letter in bar & $\begin{array}{l}\text { nowe litery do wyboru: } \\
\mathbf{b}, \mathbf{d}, \mathbf{t h}, \mathbf{f}\end{array}$ \\
\hline \multirow[t]{2}{*}{25.} & kliknięcie na b & & & & $\begin{array}{l}\text { szósta złota moneta za } \\
\text { poprawną odpowiedź } \\
\text { przycisk z literą zapala się } \\
\text { na zielono }\end{array}$ \\
\hline & & 53. & A: & $\begin{array}{l}\text { Choose the letter that says } \\
\text { p }\end{array}$ & $\begin{array}{l}\text { nowe litery do wyboru: } \\
\mathbf{p}, \mathbf{t h}, \mathbf{g}, \mathbf{d}\end{array}$ \\
\hline \multirow[t]{4}{*}{26.} & kliknięcie na d & & & & $\begin{array}{l}\text { druga brązowa moneta za } \\
\text { błędną odpowiedź, } \\
\text { przycisk z literą zapala się } \\
\text { na czerwono }\end{array}$ \\
\hline & & 54. & A: & $\begin{array}{l}\text { Almost, let's practice a bit } \\
\text { more }\end{array}$ & $\begin{array}{l}\text { Na środku ekranu napis: } \\
\text { Let's practice more }\end{array}$ \\
\hline & & 55. & A: & $\begin{array}{l}\text { Click on the letter that says } \\
\mathrm{v}\end{array}$ & $\begin{array}{l}\text { nowe litery do wyboru: } \\
\text { th, } \mathbf{c}, \mathbf{v}, \mathbf{f}\end{array}$ \\
\hline & & 56. & D: & co? nic nie rozumiem... & \\
\hline
\end{tabular}




\begin{tabular}{|c|c|c|c|c|c|}
\hline & & 57. & E: & again & \\
\hline 27. & kliknięcie na AGAIN & 58. & A: & $\begin{array}{l}\text { Click on the letter that says } \\
\mathrm{v}\end{array}$ & \\
\hline 28. & kliknięcie na v & 59. & A: & $\mathrm{vvv}$ & \\
\hline \multirow[t]{2}{*}{29.} & kliknięcie na OK & 60. & A: & Good thinking! & pierwsza złota moneta \\
\hline & & 61. & A: & $\begin{array}{l}\text { Click on the letter that says } \\
\mathrm{f}\end{array}$ & $\begin{array}{l}\text { nowe litery do wyboru: } \\
\mathbf{d}, \mathbf{t}, \mathbf{f}, \text { th }\end{array}$ \\
\hline 30. & kliknięcie na $\mathrm{f}$ & 62. & A: & fff & \\
\hline \multirow[t]{2}{*}{31.} & kliknięcie na OK & 63. & A: & Good Job & druga złota moneta \\
\hline & & 64. & A: & Find the letter that says $p$ & \\
\hline \multirow[t]{5}{*}{32.} & kliknięcie na $\mathrm{p}$ & 65. & A: & $\mathrm{p}$ & \\
\hline & & 66. & A: & Really good & trzecia złota moneta \\
\hline & & 67. & A: & $\begin{array}{l}\text { You're doing great, do you } \\
\text { want to do the test now }\end{array}$ & $\begin{array}{l}\text { Do wyboru są dwa napisy } \\
\text { YES/NO. W przypadku } \\
\text { braku wyboru po } \\
\text { kilkunastu sekundach } \\
\text { program zaprasza do } \\
\text { dalszych ćwiczeń }\end{array}$ \\
\hline & & 68. & A: & $\begin{array}{l}\text { Click on test, if you want } \\
\text { to do the test; if not, we } \\
\text { will practice more }\end{array}$ & \\
\hline & & 69. & A: & OK, let's practice more & powtórka ćwiczeń... \\
\hline
\end{tabular}

Prześledźmy ćwiczenie krok po kroku:

1-3: Pierwsze kroki to rozeznanie się w zasadach wykonania ćwiczenia.

4-17: Michalina zdobywa kolejne złote monety, co świadczy o jej znajomości liter oraz relacji głoska-litera. Drobne wątpliwości zgłasza tylko przy wyrazie big - wypowiedzi 9-11 w rubryce IV.

18-26:TEST również wykonuje poprawnie, z wyjątkami w krokach:

23: na polecenie wskazania litery oznaczającej $b$ Michalina wskazuje $p$, co jest zapewne częstym błędem, ze względu na podobieństwo brzmieniowe głosek $p$ i $b$ oraz podobieństwo graficzne odpowiadających im liter $p$ i $b$.

26: na polecenia wskazania litery oznaczającej $p$ Michalina wskazuje $d$, co także można tłumaczyć ich podobieństwem. Dalsze ćwiczenia powinny nauczyć ich dyskryminacji.

26-27:TEST został przerwany, a błędne odpowiedzi mogły zniechęcić dziecko do dalszych ćwiczeń, dlatego eksperymentator poradził naciśnięcie przycisku AGAIN, by jeszcze raz posłuchać polecenia Wirtualnej Nauczycielki.

27-32:Następne przykłady nasza uczennica wykonała bardzo dobrze, awatar zaprasza ponownie do TESTU, ale Michalina woli ćwiczyć dalej, więc wraca do ćwiczeń.

Zauważmy, że ćwiczenie skupiało uwagę tylko na wybranych literach alfabetu: f, v, b, p, i d. Inne litery pojawiały się na ekranie jako jednostki rozpraszające (distracters, Wise), mylące podobieństwem graficznym. W pozostałych ćwiczeniach FRE jednostki rozpraszające pojawiają się równie często. To, jak radzą sobie z nimi polskie dzieci wykażą następne badania.

Chcąc krótko podsumować badania wstępne, należałoby przyznać, że:

$>$ dzieci potrafią posłużyć się myszką i chętnie korzystają z CLT,

$>C L T$ jest dobrze dopasowany do dzieci w wieku 6-8 lat, nawet polskie dzieci wykonują ćwiczenia, chociaż nie jest jasne $\mathrm{w}$ jakim stopniu rozumieją polecenia awatara i stąd konieczność tłumaczenia niektórych poleceń,

$>$ forma ćwiczeń jest atrakcyjna dla dziecka, przyjazna i motywująca (monety) 
> Wirtualna Nauczycielka spełnia swoje zadanie, pomaga skupić się dziecku na wykonaniu zadania, uczy wymowy, choć nie rozumie jeszcze, co dziecko do niej mówi (rozpoznawanie mowy w ćwiczeniach $F R E$ będzie wprowadzone później)

$>$ ćwiczenia uczą i pokazują jasno co dziecko umie, a co jeszcze wymaga ćwiczeń. Przytoczone dwa fragmenty sesji z CLT potwierdzają powyższe tezy.

\section{Podsumowanie: czy elementarz XXI wieku jest nam potrzebny?}

Elementarze, poza swoją naczelną funkcją nauki czytania, od wieków służyły także inicjacji literackiej (termin Papuzińskiej za Krasowicz-Kupis, 2004) czyli „wprowadzeniu dziecka w sferę kontaktów z książką" (Krasowicz-Kupis, 2004) poprzez wspólne jej czytanie, omawianie i wartościowanie, jako przedmiotu kulturotwórczego. Rodzice, opiekunowie i nauczyciele od wieków służą jako „inicjatorzy literaccy” i przewodnicy w odkrywaniu korzyści jakie płyną z czytania. Bezsprzecznym jest fakt, że czytanie jest niezbędne dla pełnego funkcjonowania w społeczeństwie, dla czerpania z dorobku kultury i nauki, która przecież od wieków opiera się m.in. na druku. Równie niezbędna jest znajomość języka angielskiego, którego obecnie uczy się ponad miliard ludzi ${ }^{27}$. I tak jak wieki temu zabiegano o naukę łaciny, która wówczas służyła jako lingua franca nauki i kultury, tak teraz powszechnie dba się o nauczanie języka angielskiego współczesnej lingua franca. Pojawienie się nowego medium informacji, jakim jest komputer i sieć internetowa umacnia pozycję języka angielskiego. Choć trudno o dokładne dane, z pewnością większość stron internetowych jest w tym języku. Szacuje się, że stanowią one około $78 \%$ wszystkich stron i $96 \%$ stron biznesowych ${ }^{28}$. Zupełnie nowym zjawiskiem w Internecie jest digitalizacja książek rozpoczęta na skalę masową przez serwis Google. Pomysł zeskanowania i udostępnienia 15 milionów woluminów w ramach projektu Google Books został przez szefa biblioteki w Oxfordzie uznany za zwrot równie rewolucyjny, jak wynalazek Gutenberga ${ }^{29}$. Wobec powyższego oczywiste jest, że znajomość języka angielskiego, a także obsługi komputera jest potrzebna każdemu dziecku, i to nie tylko w Polsce. Dzieci z łatwością już uczą się korzystać z komputera, najchętniej grając w gry komputerowe, a rzadziej dla pozyskiwania wiedzy. Dlatego wprowadzenie programów edukacyjnych, elektronicznych elementarzy XXI wieku, takich jak prezentowany tu CLT jest pilnym dezyderatem, nie tylko ze względu na jego główny cel - nauki czytania, lecz także ze względu na jego funkcje inicjacyjna w kontakcie z komputerem. I trzeba dziecko nauczyć korzystać z komputera mądrze!

\section{Podziękowania}

Opisane badania wstępne nie byłyby możliwe bez pomocy szeregu osób, którym należą się podziękowania ze strony autora. Szczególnie autor chciałby podziękować dzieciom, które chętnie zgodziły się wziąc udział w badaniach oraz dyrektorkom: Joannie Radajewskiej (dyr. Anglojęzycznego Przedszkola Prywatnego w Poznaniu „Akademia Smyka” i Agacie Ludwie (dyr. Spotecznej Szkoty Podstawowej nr 2 w Poznaniu).

\footnotetext{
${ }^{27}$ Dane szacunkowe na podstawie informacji na stronie http://englishenglish.com/english_facts_7.htm.

${ }^{28} \mathrm{http} / / / \mathrm{www}$. sims.berkeley.edu:8000/research/projects/how-much-info/internet.html\#6

"State of the Internet 2000," United States Internet Council \& ITTA Inc., http://www.usinternetcouncil.org/

${ }^{29}$ Pomysł jest także kontrowersyjny ze względów prawnych, pojawiły się także protesty Francuskiego rządu obawiającego się o swój język narodowy; lecz rezultaty już są widoczne w Internecie http://print.google.com/googlebooks/about.html
} 


\section{Bibliografia:}

Bogacka, A. 2006. Dziubalska-Kołaczyk, K., Krynicki, G., Pietrala, D., Wypych, M. (2006)

General and Task-Specific Corpus Resources for Polish Adult earners of English. [w:] Proceedings of the LREC 2006 Conference. Genua, Włochy

Cassirer, E. 20o4. Symbol i język. Poznań: Wydawnictwo Naukowe Wyższej Szkoły Pedagogiki i Administracji w Poznaniu.

Cole, R., et al. 2003. Perceptive Animated Interfaces: First Steps Toward a New Paradigm for Human Computer Interaction [w:] Proceedings of the IEEE: Special Issue on Multimodal Human Computer Interface. artykuł dostępny w Internecie pod adresem: http://CSLR.colorado.edu/beginweb/perceptive_animated_interfaces/perceptive_animated_interfaces.html

Czarnik, J. 2004. Elementarze prapradziadków: Wystawa w Galerii Książki [w:] Biuletyn EBIB (red. Bożena BednarekMichalska) Nr 3/2004 (54) marzec. - Czasopismo elektroniczne. - [Warszawa]: Stowarzyszenie Bibliotekarzy Polskich KWE, 2004. artykuł dostępny w Internecie pod adresem: http://ebib.oss.wroc.pl/2004/54/czarnik.php.

Daniels, M. 2001. Dancing with words: signing for hearing children's literacy. Westport: Bergin \& Garvey.

Dziubalska-Kołaczyk, K., Bogacka, A., Pietrala, D., Wypych, M., Krynicki, G. (2006). PELT: An

English language tutorial system for Polish speakers. [w:] Proceedings of the MultiLing

Conference. Stellenbosch, South Africa.

Gregory, M. 2005. Google's books online under fire BBC News. artykuł dostępny w Internecie pod adresem: http://news.bbc.co.uk/1/hi/business/4576827.stm

Kail, R. V, Cavanaugh, J., 2004. Human development: a life-span view. 3rd ed. Belmont, CA: Thomson/Wadsworth.

Kamińska, K. 1999. Nauka czytania dzieci $w$ wieku przedszkolnym. Warszawa: Wydawnictwa Szkolne i Pedagogiczne SA

Karpiński, M. 1998. Psycholingwistyczne aspekty komunikacji człowiek-komputer. Poznań: UAM.

Krasowicz-Kupis, G. 2004. Rozwój świadomości językowej dziecka. Lublin: UMCS.

Łobacz, P. 1996. Świadomość fonologiczna dzieci. [w:] Biuletin de la Societe Polonaise de Linguistique, fasc. LII.

Rocławski, B. [nie podano roku wydania] Klocki LOGO. do zabawy i nauki wymowy, czytania, pisania, ortografii i matematyki Gdańsk: Biblioteczka Pedagogiczna - Glottispol Gdańsk.

Taboł, S., 2005. Istota czytania. Kraków: Oficyna Wydawnicza Impuls.

Takahashi, T., Takeda, H. 2001. TelMeA: An Asynchronous Community System with Avatar-like Agents [w:] International Conference on Human-Computer Interaction (International Federation for Information Processing). Human-computer interaction: INTERACT '01: IFIP TC.13 International Conference on HumanComupter Interaction, $9^{\text {th }}-13^{\text {th }}$ July 2001, Tokyo, Japan. Edited by Michitaka Hirose.N. (strony 190-197)

Tinker, M. 1980. Podstawy efektywnego czytania. Warszawa: Państwowe Wydawnictwa Naukowe.

Wise, B. et al. [w druku]. Learning to Read with a Virtual Tutor: Foundations Literacy. [w:] Kinzer, C. \& Verhoeven, L. (Eds). Interactive Literacy Education. Mahwah, NJ: Lawrence Erlbaum. artykuł dostępny w Internecie pod adresem: http://CSLR.colorado.edu/beginweb/virtual_tutor/virtual_tutor.html

Wolf, M., Vellutino, F., Gleason, J. B. 2005 Psycholingwistyczna analiza czynności czytania. [w:] Gleason, J. B., Ratner, N. B. (red.) Psycholingwistyka. Gdańsk: Gdańskie Wydawnictwo Psychologiczne.

Źródła internetowe sprawdzono 30 stycznia 2006 roku. 